\title{
A PROCEDURE FOR TESTING CORED ICE UNDER UNIAXIAL TENSION
}

\author{
By RUSSELL W. LEE
}

(Thayer School of Engineering, Dartmouth College, Hanover, New Hampshire 03755, U.S.A.)

\begin{abstract}
A procedure is described for testing cored ice specimens under uniaxial tension. The procedure incorporates an end-capping system described by Cole and others (1985), two carpeted Synthane end caps, and extensometers mounted directly on the ice. Use of the procedure has resulted in a successful test rate of $75 \%$.
\end{abstract}

RÉSUMÉ. Un procédé de test en compression uniaxiale des carottes de glace. On décrit un procédé de test en compression uniaxiale pour des carottes de glace. Il necessite le frettage décrit par Cole et alt. (1985) plus deux embouts carpetés en Synthane, ainsi que des extensomètres placés

\section{INTRODUCTION}

Cole and others (1985) described a system for mounting end caps on ice-core specimens that typically achieves end-plane parallelism within $0.5 \mu \mathrm{m} / \mathrm{mm}$ of specimen diameter. The importance of nearly parallel end planes for successful tensile testing has been discussed by Lee and others (1984). (A successful test results in fracture normal to the tensile axis within the central third of a right-circular cylinder.) Using the procedure described here, approximately 45 right-circular cylinders of both Arctic sea ice and laboratory-grown saline ice have been prepared and successfully tested under uniaxial tension.

\section{PROCEDURE}

The system and procedure described by Cole and others (1985) for attaching end caps to cored ice specimens was followed in the development of this procedure with one important exception. Instead of using end caps whose bonding surfaces had been machined with concentric grooves, end caps were used which had jute-backed carpeting bonded to their ice-bonding surfaces with epoxy resin. As discussed by Lee and others (1984), the addition of a layer of jute-backed carpeting provides sufficient compliance at the ice/end-cap interface to prevent the development of large shear stresses in the end zones during testing. Minimizing shear stresses at the end zones prevents the need for reducing the cross-sectional area within the gage section. Additionally, the carpeting enhances the strength of the ice/end-cap bond.

An end cap with jute-backed carpeting is shown on the system in Figure 1. The procedural differences from those outlined by Cole and others are: (1) the carpeting is soaked in distilled water at $0^{\circ} \mathrm{C}$ until saturated; (2) a latex membrane is placed around the carpeted end cap and distilled water at $0^{\circ} \mathrm{C}$ is added to re-saturate the carpeting; and (3) once the ice is brought into contact with the carpeting, the water is allowed to freeze for approximately $1 \mathrm{~h}$ before removal of the specimen. The latex membrane keeps the water in place during freezing and accommodates freezing strains.

To measure accurately and control sample deformation during testing, extensometers are mounted on holders (Fig. 2) which attach directly to the ice. The holders were directement sur la glace. L'utilisation de ce procédé a rendu possible des tests jusqu'à des taux de $75 \%$.

Zusammenfassung. Ein Verfahren zur Prüfung von Eisbohrkernen unter einachsiger Dehnung. Es wird ein Verfahren zur Prüfung von Eisbohrkernen unter einachsiger Dehnung beschrieben. Das Verfahren stützt sich auf ein System von Endkappen, wie es von Cole et al. (1985) dargestellt wird, zwei gepolsterte Synthane-Endkappen und Dehnungsmesser, die direkt auf das Eis montiert sind. Die Anwendung des Verfahrens ergab Prüfergebnisse mit einer Erfolgsrate von $75 \%$.

originally designed for use on fresh-water ice specimens and contain spring-loaded hinges for easy mounting (see Lee, unpublished). The holders are frozen to the specimen using a small amount of cooled water. They were machined so that the springs are unstressed when the mounts are in place, thus preventing disturbance of the uniaxial stress state at their points of contact. Four spacer rods provide a consistent gage length and are removed prior to testing. The extensometers are mounted on rods extending towards the central region of the sample and measure the relative displacement of the holders during testing. While using these

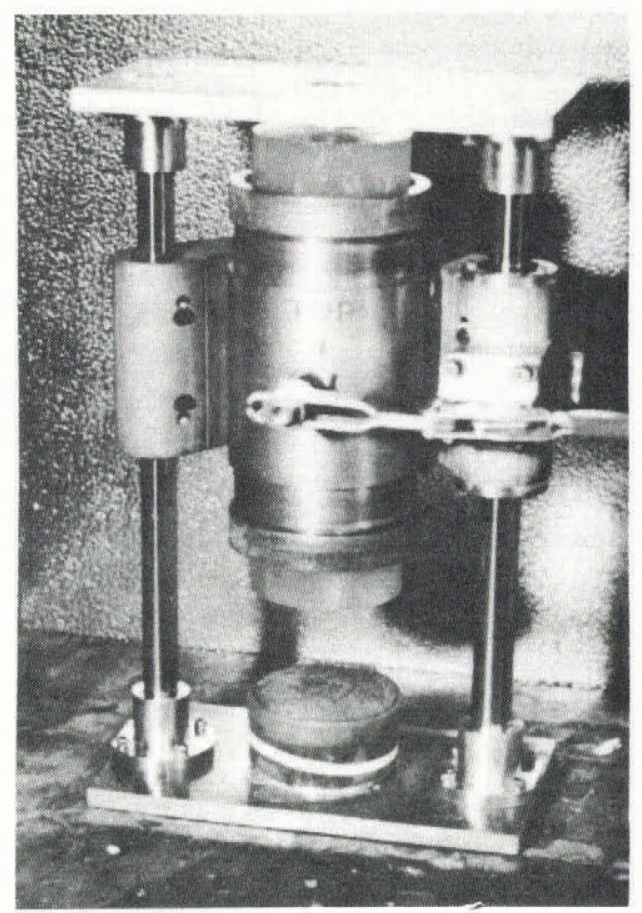

Fig. 1. Carpeted end cap surrounded by latex membrane on the end-capping system described by Cole and others (1985). 


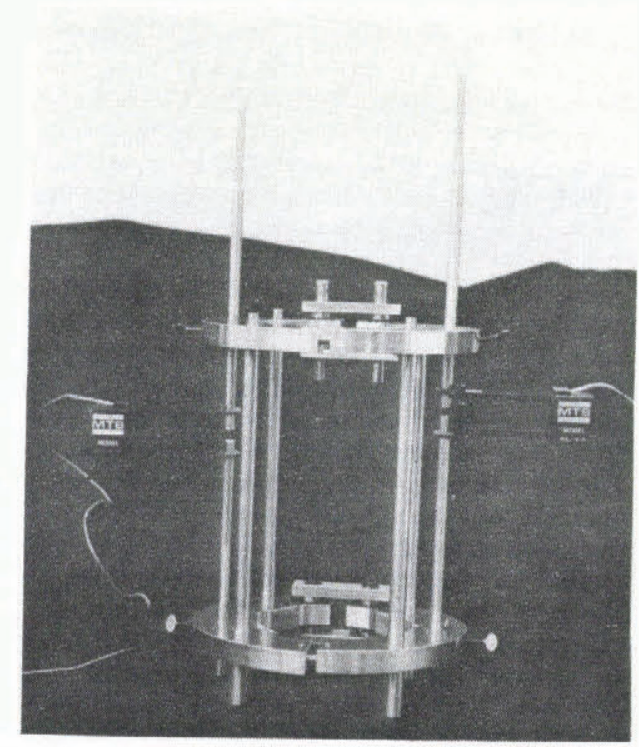

Fig. 2. Extensometer holders which are frozen directly to the ice specimen. The four spacer rods are removed prior to testing.

mounts, initial failure has never been observed to initiate near their contact points.

\section{RESULTS OF THE PROCEDURE}

The procedure has been used to test 60 specimens under tension at $-10^{\circ} \mathrm{C}$ and at constant strain-rates of $10^{-3} \mathrm{~s}^{-1}$ and $10^{-7} \mathrm{~s}^{-1}$. The average end-plane parallelism of these specimens was $0.45 \mu \mathrm{m} / \mathrm{mm}$ of specimen diameter with a standard deviation of $0.17 \mu \mathrm{m} / \mathrm{mm}$. The success rate was $75 \%$. Figure 3 illustrates a typical case for a laboratory-grown saline ice specimen strained parallel to its growth direction.

\section{ACKNOWLEDGEMENTS}

We wish to thank D. Cole of the US Army Cold Regions Research and Engineering Laboratory, Hanover, New Hampshire, for use of the end-capping system. We also thank R. Roberts, of US Army CRREL, and E. Schulson, of the Thayer School of Engineering, for valuable

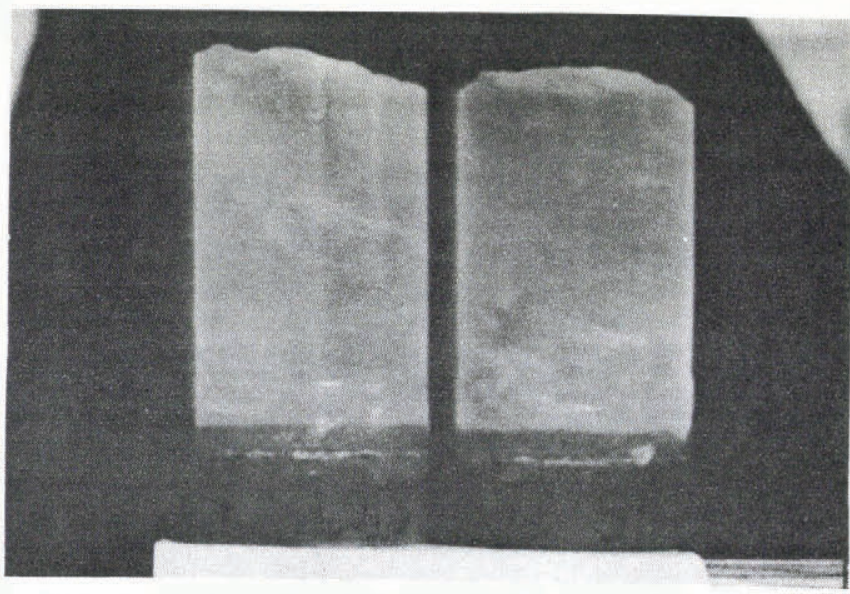

Fig. 3. Laboratory-grown saline ice specimen fractured under tension at $-10^{\circ} \mathrm{C}$ at $10^{-7} \mathrm{~s}^{-1}$. Vertical orientation. Tensile strength: $1.06 \mathrm{MPa}$. Melt-water salinity: $3.7 \%$. Specimen density: $0.90 \mathrm{Mg} / \mathrm{m}^{3}$.

assistance. The work was funded through a grant from the Ice Research Laboratory, Dartmouth College, which is funded by a consortium of the following firms and federal agencies: Amoco, Exxon, Mobil, Shell, Sohio, Minerals Mangement Service, Maritime Administration, and the National Science Foundation.

\section{REFERENCES}

Cole, D.M., and others. 1985. A system for mounting end caps on ice specimens, by D.M. Cole, L.D. Gould, and W.B. Burch. Journal of Glaciology, Vol. 31, No. 109, p. 362-65.

Lee, R.W. Unpublished. The effect of grain size on the tensile strength of ice at two strain-rates. [M.Sc. thesis, Thayer School of Engineering, Dartmouth College, Hanover, NH, 1985.]

Lee, R.W., and others. 1984. A procedure for testing polycrystalline ice in uniaxial tension, by R.W. Lee, J.H. Currier, P.N. Lim, and E.M. Schulson. Journal of Glaciology, Vol. 30, No. 105, p. 246-47. 